\title{
Pasja jako istotny wymiar doświadczania pracy
}

Passion as an Essential Aspect

of Work Experience

\begin{abstract}
ABSTRAKT
Praca w życiu człowieka pełni rolę osobista i społecznq. Refleksja nad zrozumieniem jej istotnego znaczenia jest konieczna do tego, by właściwie włączyć pracę do życia. Właściwe włączenie polega na tym, że stanowi ona z życiem harmonijnq całość i jest źródłem poczucia sensu i radości.

W artykule wskazano różne sposoby doświadczania pracy: jako źródła środków materialnych, obowiq̨zku społecznego, kształtowania tożsamości, przestrzeni samorealizacji, pozycji społecznej oraz nawiqzzywania kontaktów z innymi osobami. Zwrócono uwagę na zwiqzek jakości wykonywania pracy z tym jej wymiarem, który nazwano pasja. Wyjaśniono czym jest pasja oraz czym charakteryzuje się osoba wykonująca pracę z pasja. Pokazano znaczenie pasji na przykładzie badań amerykańskiego psychologa Mihály'a Csíkszentmihályiego. Autor przez ponad 25 lat prowadził badania, w których starał się wyjaśnić dlaczego jedne osoby doświadczaja maksymalnego przeżywania wykonywanej czynności, a inne nie, chociaż wykonują tę samq czynność. Na ich podstawie opracował teorię przepływu (flow theory).
\end{abstract}

SLOWA KLUCZOWE praca, doświadczanie pracy, jakość pracy, pasja, instrumentalizacja pasji

KEYWORDS

work, work experience, quality of work, passion, instrumentalisation of passion

SPI Vol. 20, 2017/2

ISSN 2450-5358

e-ISSN 2450-5366

DOI: 10.12775/SPI.2017.2.003

Articles and dissertations 
Konsekwencja braku pasji jest przeciętność osiqganych rezultatów pracy. Negatywne konsekwencje pojawiaja się również wtedy, gdy człowiek traktuje pasję instrumentalnie, czyli jako środek do osiagnięcia innych sukcesów. W artykule scharakteryzowano przykłady takiego nastawienia współczesnego człowieka do pasji.

Prawdziwa pasja trwa dopóki jest przestrzeniq wolności osoby i nie wynika z żadnej konieczności. Pedagogiczna interpretacja powinna więc być skoncentrowana na tworzeniu warunków sprzyjających kształtowaniu i rozwijaniu pasji, a nie wskazywaniu do czego może się ona przydać.

\section{ABSTRACT}

Working plays a relevant role in both personal and social life. Reflections on understanding its importance are necessary for accurately harnessing it for life, ensuring that it is in harmony with our whole life and serves $s$ a source of sense of meaning and joy.

The article indicates the different ways of experiencing work: as a source of material resources, social obligation, shaping identity, self-realization, determining social status and to establish contacts with other people. Attention has been drawn to the connection between the quality of work with the dimension which is called passion. Passion is defined together with what makes a person perform their work with passion. The importance of passion has been shown on the example of the research of American psychologist Mihály Csíkszentmihályi. For more than 25 years the author led a study through which he tried to explain why some people feel the maximum while others do not, although both execute the same operation. From its results, he developed flow theory.

The consequence of the lack of passion is the mediocrity of work results. Negative consequences also arise when a person treats passion instrumentally, that is, as a means to gain more success. The article describes examples of such an attitude towards passion.

True passion continues until it remains a genuine space for personal freedom and it is not the result of any necessity. Therefore, the pedagogical interpretation should be focused on creating the conditions conducive to the formation and development of passion, not indicating what might it be useful for. 
Praca w życiu człowieka pełni rolę osobistą i społeczną. Refleksja nad zrozumieniem jej istotnego znaczenia jest konieczna do tego, by właściwie włączyć pracę do życia. Właściwe włączenie polega na tym, że stanowi ona $\mathrm{z}$ życiem harmonijną całość i jest źródłem poczucia sensu i radości.

Praca jest dla człowieka dobrem trudnym, wymaga bowiem pokonania stanu bierności ${ }^{1}$. Przynosi jednak wymierne korzyści: jej celem jest przekształcanie otaczającej rzeczywistości, czyniąc ją użyteczną dla człowieka. Sprawcze działanie jest też źródłem doskonalenia samego człowieka poprzez aktualizowanie jego rozwojowej potencjalności. Praca jest więc dobrem osobowym i ekonomicznym. Jest warunkiem dojrzałego formowania własnego człowieczeństwa.

W praktyce życia codziennego różne jest pojmowanie pracy przez człowieka: od konieczności po sposób bycia dla innych, czyli od przymusu po miłość. Teolog i psycholog Marek Dziewiecki zauważył:

Ci, którzy mało kochają, mało też pracują. Z kolei ci, którzy starają się pracować mimo to, że nikogo nie kochają, czynią to z błędnych motywów, na przykład $z$ chęci zrobienia kariery czy dla samych pieniędzy. Tacy ludzie nie doświadczają radości życia. Przeciwnie, popadają w uzależnienie od pracy (pracoholizm) lub w ogóle z niej rezygnują i usiłują żyć kosztem innych ludzi ${ }^{2}$.

Refleksja nad doświadczaniem pracy, podjęta w niniejszym tekście, jest więc skierowana nie tylko do osób pracujących, ale także do tych, które nie mają naglącej potrzeby pracy dzięki nagromadzonym środkom lub prowadzą działalność szkodliwą dla społeczeństwa; rezygnują z pracy jako dobra godziwego, czyli odpowiadającego godności człowieka, wyrażającego tę godność i ją pomnażającego. Uchylanie się człowieka od pracy jest stanem patologicznym, ponieważ praca służy samodoskonaleniu i twórczemu udziałowi w doskonaleniu innych osób. Analogicznie pozbawienie człowieka możliwości pracy (bezrobocie) jest niezgodne z jego godnością. Zygmunt Freud zapytany o receptę na szczęście człowieka, odpowiedział: „praca i miłość”’

1 M. Krąpiec, Ludzki wymiar pracy, „Człowiek w Kulturze” 2005, nr 17, s. 10.

2 M. Dziewiecki, Przedmowa, w: A. Grün, Życie i praca-duchowe wyzwanie, tłum. B.M. Kamińska, Częstochowa 2007, s. 7.

3 Cyt. za M. Csíkszentmihályi, Przeptyw, tłum. M. Wajda-Kacmajor, Taszów 2005, s. 256. 
Praca chroni człowieka przed co najmniej trzema wielkimi chorobami społecznymi: próżniactwem, występkiem i ubóstwem ${ }^{4}$. Człowiek może jednak wobec pracy przyjąć różne nastawienie, decydujące o sposobie jej doświadczania. Celem artykułu jest zwrócenie uwagi na związek jakości wykonywania pracy i sposobu jej doświadczania z tym jej wymiarem, który nazwano pasją.

\section{Sposoby doświadczania pracy}

Poszczególne modele życia społecznego łączy wspólna wartość: jest nią praca człowieka. Nastawienie człowieka wobec pracy kształtuje się między innymi w zależności od tego, jakie ma wobec niej oczekiwania. Można postrzegać pracę przez pryzmat korzyści ekonomicznych, kształtując nastawienie instrumentalne lub przez pryzmat samorealizacji, wyrabiając $\mathrm{w}$ sobie nastawienie podmiotowe. Poprzez określone nastawienie wobec pracy człowiek wyraża swoje oczekiwania wobec życia, siebie i innych oraz ujawnia kim jest lub kim chciałby być jako osoba i członek społeczności. Jest to przestrzeń istotna do interdyscyplinarnego zinterpretowania, w tym wskazania pedagogicznych wniosków dla teorii i praktyki wychowania, dotyczących kształtowania wartościowych nastawień wobec pracy w kontekście właściwego włączania pracy do życia. Doświadczanie pracy jako źródła zaspokojenia zróżnicowanych potrzeb czyni ją wartością konieczną do realizacji celów życiowych, a więc także związaną z poczuciem sensu i radości.

Pedagog Waldemar Furmanek zaproponował interesującą typologię nastawień człowieka wobec pracy. Typologiczny charakter uporządkowania tego obszaru pozostawia miejsce dla dokonywania zmian adekwatnych do dynamicznie zmieniającej się rzeczywistości społecznej: można poszerzyć ten podział nastawień o kolejne typy lub modyfikować ich charakterystykę. Autorski podział obejmuje :

4 V. del Mazza, Bajki i madrość życiowa, tłum. L.T. Karłowicz, Warszawa 1999, s. 70.

5 W. Furmanek, Rozumienie wartości pracy a orientacje życiowe cztowieka, „Pedagogika Pracy" 2004, nr 45, s. 62-66. 
1. Pracę rozumianą jako konieczność życiową człowieka wywołaną przymusem ekonomicznym. Nastawienie to ma miejsce wtedy, gdy osoba traktuje pracę wyłącznie lub przede wszystkim jako źródło niezbędnych środków materialnych. Mniej istotny jest charakter i rodzaj pracy: może to być praca wykonywana w bardzo trudnych warunkach albo niezgodna z posiadanymi kwalifikacjami czy kompetencjami. Decyzja o jej podjęciu oraz poczucie odpowiedzialności pracownika są zdeterminowane motywami ekonomicznymi. Ważne jest wykonanie obowiązków w wyznaczonym czasie, a nie sens wykonywanej pracy. Człowiek nie poszukuje w niej radości ani spełnienia; traktuje ją instrumentalnie. $\mathrm{Na}$ ogół włożony wysiłek ocenia subiektywnie jako większy niż wartość wynagrodzenia, a to sprzyja bardziej niezadowoleniu. Nie utożsamiania się więc z miejscem pracy. Można je zmienić w każdej chwili, jeśli tylko pojawi się oferta o większych walorach ekonomicznych. Pracownik nie dba o lojalność, na ogół prezentuje postawy roszczeniowe.

2. Pracę postrzeganą jako obowiązek człowieka. Źródłem tego nastawienia jest przekonanie, że każdy, kto może pracować, jest do tego zobowiązany dla pokazania swojej osobowej i społecznej przydatności. Konsekwencją takiego podejścia jest traktowanie obowiązków związanych z pracą niezwykle solidnie i odpowiedzialnie. Są one jednak postrzegane instrumentalnie, jako sposób podwyższenia własnego statusu materialnego i społecznego. W odróżnieniu od poprzedniego nastawienia, tutaj przy wyborze pracy są jednak brane pod uwagę takie elementy, jak sens pracy, jej cele i warunki realizacji oraz własne możliwości. Sprzyja to poczuciu wyboru dobrego miejsca i charakteru pracy, więc przekłada się też na wysoki stopień lojalności i odpowiedzialności. Osoba przestrzega regulaminu pracy, stopniuje ważność zadań, oddziela pracę od innych sfer życiowej aktywności. Doświadcza tego, że jest dobrym pracownikiem, co mobilizuje ją do doskonalenia, a to z kolei jeszcze bardziej zwiększa satysfakcję, co skutkuje silnymi więziami z zawodem i miejscem pracy. Jest przesłanką do zmiany nastawienia wobec pracy z instrumentalnej na podmiotową.

3. Pracę rozumianą jako możliwość realizacji potrzeby identyfikacji i tożsamości osobowej. Nastawienie to jest przykładem podmiotowej interpretacji, która obejmuje rozumienie pracy jako formy 
zmieniania siebie i świata. Osoba o takim nastawieniu oczekuje od pracy nie tylko satysfakcji, lecz także możliwości własnego rozwoju. Jest odpowiedzialna za podejmowane zadania, ale też za siebie i wobec siebie. Systematycznie i wytrwale dąży do mistrzostwa w pracy, co współwystępuje z podnoszeniem stopnia identyfikacji społeczno-zawodowej. Sprzyja kształtowaniu nastawienia o jeszcze wyższym nasyceniu podmiotowości, czyli potraktowaniu pracy jako sposobności do samorealizacji.

4. Pracę widzianą jako droga i teren samorealizacji człowieka. Takie nastawienie oznacza odkrywanie samego siebie, swoich mocnych stron poprzez pracę. Dla osoby o tym nastawieniu naturalne jest utożsamienie celów i planów zawodowych z życiowymi. Praca stanowi integralną część życia, a zadowolenie z jej wykonywania jest istotną częścią radości życiowej. Takie rozumienie pracy, ale też rozumienie siebie i otaczającej rzeczywistości, skutkuje korzystnymi z punktu widzenia osoby decyzjami: wyboru kierunku działania, doboru metod, form i środków realizacji zamierzeń. Jest ona umotywowana do działania, twórcza, traktuje trudności jako naturalne bariery, których pokonanie jest ważnym elementem rozwoju. Warunkiem owocności takiego nastawienia jest adekwatne rozpoznanie swoich możliwości i zainteresowań.

5. Pracę postrzeganą jako oznaka prestiżu społecznego. Źródłem takiego nastawienia są aspiracje osoby do zajmowania określonej pozycji społecznej. Treść pracy różnicuje jej znaczenie osobowe i społeczne, wpływając na tę pozycję. W procesie wychowania człowiek poznaje to zróżnicowanie, więc wybiera taką drogę kształcenia, która umożliwia mu zdobycie kwalifikacji adekwatnych do jego aspiracji w tym zakresie. Praca ma przez to szansę stać się przestrzenią samorozwoju i uzyskania oczekiwanego prestiżu społecznego.

6. Pracę rozumianą jako szansa na budowanie więzi społecznych oraz jako możliwość zaspokojenia potrzeby kontaktów społecznych. Źródłem takiego nastawienia jest bardzo silna potrzeba kontaktów społecznych. Stanowi ona podstawowy motyw wyboru i podejmowania pracy. Może charakteryzować np. osoby na emeryturze lub rencie, które z własnej woli nie zamierzają jeszcze zaprzestać aktywności zawodowej i w związku z tym silnie odczuwają nagła zmianę trybu życia, między innymi ograniczenie kon- 
taktów interpersonalnych. Nastawienie tego typu mogą też mieć osoby, które nie pracują z innego powodu, np. kobiety prowadzące gospodarstwa domowe. Takie nastawienie może skutkować podejmowaniem pracy nieadekwatnej do własnych zainteresowań lub możliwości albo bardzo nisko uposażanej, ponieważ najważniejsza w pracy jest wówczas możliwość kontaktu z innymi.

W każdym z powyższych przypadków można być bardziej lub mniej zadowolonym $z$ wykonywanej pracy, włącznie ze stanem braku zadowolenia. Można poprzez pracę bardziej lub mniej realizować siebie, swoje plany i marzenia, włącznie ze stanem braku spełniania siebie. Istnieje bowiem taki wymiar pracy, który dopełnia jej wartość bez względu na wysokość zarobków i prestiż. To wymiar, który według psychologów decyduje o jakości wykonywanych zadań, wręcz rodzi profesjonalizm ${ }^{6}$. Jest to pasja.

\section{0 istocie pasji}

Obrazowo mówiąc, można stwierdzić, że człowiek, który pracuje rękoma jest pracownikiem fizycznym; człowiek, który pracuje rękoma i głową jest rzemieślnikiem; człowiek pracujący rękoma, głową i sercem jest artystą, i to bez względu na to, jakiego rodzaju pracę wykonuje $^{7}$. O jakości doświadczania pracy decyduje bowiem nie tylko to, jaką pracę człowiek wykonuje, ale też to $\mathrm{jak}$ ją wykonuje. Chiński filozof i myśliciel Konfucjusz powiedział: „Wybierz sobie zawód, który lubisz, a całe życie nie będziesz musiał pracować"».

Źródło pasji tkwi wewnątrz osoby. Wynika $\mathrm{z}$ tego pewna trudność w mówieniu o pasji. Jest ona bowiem wartością przeżywaną, egzystencjalną. Chociaż jest całkowicie osobista i niepowtarzalna, to jednak zawsze przeżywana w relacji z innymi i wśród innych; dotyka istoty ludzkiej egzystencji. Maria Dudzikowa i Marian Nowak, autorzy opracowania dotyczącego pasji, zwracają uwagę, że:

6 Por. J. Walkiewicz, Petna moc możliwości, Gliwice 2015, rozdz. 6.

7 Por. V. del Mazza, Bajki i madrość życiowa, dz. cyt., s. 75.

8 Cyt. za: S.L. Popek, O istocie i mechanizmach pasji, w: O pasjach cudzych $i$ wtasnych-profesorowie, red. M. Dudzikowa, M. Nowak, Lublin 2015, s. 16.

9 M. Dudzikowa, M. Nowak, Wprowadzenie, w: O pasjach cudzych $i$ wtasnychprofesorowie, red. M. Dudzikowa, M. Nowak, Lublin 2015, s. 8. 
Pasja stanowi doświadczenie niekomunikowalne, lecz przeżywane i doświadczane we wzajemnych relacjach, gdy po prostu przez świadectwo własnego zaangażowania komunikujemy (nawet bez słów) innym to, co stanowi treść i siłę wewnętrzną naszej determinacji w działaniu i tworzeniu ${ }^{10}$.

Spostrzeżona trudność, wpisana w istotę pasji, może być jednym z powodów, dla których w ostatnim ćwierćwieczu pasja jako zjawisko i właściwość nie stała się przedmiotem poważnego potraktowania $\mathrm{w}$ profesjonalnych opracowaniach naukowych $\mathrm{z}$ zakresu nauk humanistycznych i społecznych. Trudno jest też znaleźć w podstawowych słownikach psychologicznych czy pedagogicznych określenie tego, czym jest pasja. Według Stownika jezzyka polskiego pasja jest to „silne, namiętne przejęcie się czymś"11. Odniesiona do działania, nadaje mu charakter zamiłowania, czyli postępowania pełnego zapału i entuzjazmu w zajmowaniu się czymś interesującym. Nie można jednak na tej podstawie stwierdzić, że praca z pasją jest łatwa. Wręcz przeciwnie: pasja oznacza bowiem połączenie namiętności, cierpliwości i... cierpienia, jak głosi Stownik etymologiczny jezzyka polskiego Aleksandra Brücknera ${ }^{12}$. Jest to zgodne z łacińską etymologią słowa: passio, passionis oznacza cierpienie ${ }^{13}$. Można przyjąć, że związek pasji z cierpieniem ma charakter pierwotny. Ma bowiem swoje źródło w ewangelicznym opisie męki Chrystusa. Pasyjka to mały krucyfiks, a pasyjny charakter ma okres Wielkiego Postu, będący czasem rozpamiętywania Męki Pańskiej. Obydwa rozumienia pasji, jako zamiłowania i cierpienia, zostają współcześnie poszerzone o użycie tego terminu w jego zupełnie nowym odcieniu znaczeniowym, jako silnego gniewu i furii. Na przykład „doprowadzić kogoś do pasji” nie oznacza stworzenia warunków do wzbudzenia lub rozwijania zainteresowań/ zamiłowań osoby, lecz znaczy bardzo silnie ją zdenerwować; podobnie „wpaść w szewską pasję” oznacza gniew i wściekłość osoby. Trudno jednak dać normatywne przyzwolenie na tak szerokie użycie tego terminu, jakie można spotkać w języku biznesowym, np. ,naszą pasją jest świadczenie usług na najwyższym poziomie”, bowiem jakość

10 Tamże, s. 8-9.

11 Stownik jezyka polskiego, t. 1, red. M. Szymczak, Warszawa 1979, s. 613.

12 Por. A. Brückner, Stownik etymologiczny jezyka polskiego, Warszawa 2000, s. 398.

13 J. Pieńkos, Stownik tacińsko-polski. Eacina w nauce i kulturze, Kraków 2001, s. 318 . 
usług w pierwszym rzędzie kojarzy się z kwalifikacjami i kompetencjami. Odniesienie to należy raczej uznać za reklamowe nadużycie słowa pasja. Wykorzystuje ono jednak realny związek zauważany między jakością pracy i pasją z jaką się ją wykonuje.

\section{Pasja jako źródło jakości pracy}

Socjolog Marek Krajewski skonkretyzował, że pasja charakteryzuje osobę ${ }^{14}$ :

a) która poświęca się jakiemuś zajęciu bez reszty i to bez względu na koszty, opinie innych czy stopień, w jakim działanie to przynosi jej uznanie;

b) dla której zajęcie to stanowi podstawową formę samorealizacji i fundament tożsamości, a nie tylko przyjemny sposób spędzania wolnego czasu, relaksu, odstresowania; pasja więc to nie to samo, co hobby czy zainteresowania;

c) która odczuwa wobec tego co robi niezwykle silne emocje, przypominające nieco miłość, i która nie traktuje własnego zajęcia w sposób instrumentalny; przeciwnie - ma ono dla niej charakter wewnątrznagradzający; wystarczającym benefitem jest możliwość jego urzeczywistniania i realizacji;

d) która sama decyduje, co jest przedmiotem jej pasji; nie jest w żaden zewnętrzny sposób zmuszona do jej realizowania; jedyne co ją do tego zachęca to silne, wewnętrzne pragnienie obcowania z przedmiotem pasji.

Każda $\mathrm{z}$ wymienionych cech wydaje się powszechna, a jednak występowanie wszystkich jednocześnie u konkretnej osoby powoduje, że pasja staje się szczególnym sposobem bycia, w tym odnoszenia się do wykonywanej pracy.

Kluczem do pracy wykonywanej z pasją jest poczucie sensu tego, co się robi. Ten sens wynika z połączenia myśli, działania i wyniku tego działania ${ }^{15}$. Potwierdzają to ponad 25-letnie badania amerykańskiego psychologa węgierskiego pochodzenia Mihály’a Csíkszentmihályiego, wspóltwórcy psychologii pozytywnej, a dotyczące teorii

14 M. Krajewski, Pasja i formy jej degeneracji, w: O pasjach cudzych $i$ wtasnych profesorowie, red. M. Dudzikowa, M. Nowak, Lublin 2015, s. 38.

15 J. Walkiewicz, Petna moc możliwości, dz. cyt., s. 89. 
optymalnego doświadczenia. Autor oparł tę teorię na koncepcji przepływu (flow theory) ${ }^{16}$, w której wskazuje na to, co sprawia, że jedni doświadczają maksymalnego przeżywania wykonywanej czynności, a inni nie, chociaż wykonują tę samą czynność.

Optymalne doświadczenie jest przeżywaniem głębokiego sensu działania. Sensowność oznacza nadawanie znaczenia czynnościom, tak by koncentrowały uwagę (wysiłki i starania) oraz angażowały, dając poczucie radości ich wykonywania. Ta specyfika dotyczy każdej czynności: np. obierania ziemniaków dla swojej rodziny, jak i czynności zawodowych. „Scalenie” czynności zawodowych następuje poprzez podporządkowanie ich nadrzędnej wartości w pracy. Rodzi to poczucie tzw. „wewnętrznej celowości” ${ }^{17}$, wpływającej na zgodność myśli, uczuć i działań osoby. Jeśli znaczenie ma każda czynność wykonywana w teraźniejszości oraz z perspektywy przeszłości i przyszłości, to sens ma całe działanie zawodowe ${ }^{18}$. To poczucie sensu jest właśnie kluczem do pracy pełnej pasji: kiedy robimy coś, co jest dla nas znaczące, „wkładając w to całego siebie, swoje serce i swój umysł, to chcemy robić to coraz lepiej. Rozwijamy i udoskonalamy, poszukujemy i odkrywamy"19 - napisał psycholog Jacek Walkiewicz, który podkreśla, że pasja rodzi profesjonalizm ${ }^{20}$.

Z koncepcji przepływu M. Csíkszentmihályiego wynika, że sensu nie należy „tylko” szukać, lecz sens należy nadawać - nadawać wartość wykonywanej czynności. Podstawą jest więc poczucie sensu indywidualnego, co nie wyklucza sensu w szerszym, społecznym wymiarze. Można więc wykonywać pracę społecznie poważaną i wysoko uposażaną, a być nią znudzonym; można też wykonywać pracę, stojąc w fabryce przy taśmie produkcyjnej, powielając te same czynności przez wiele godzin i być szczęśliwym. Radość z wykonywanej pracy jest bowiem związana $\mathrm{z}$ umiejętnością nadawania wartości tej pracy. Stąd można wskazać, że pasja nie czyni pracy łatwą,

16 Koncepcja została przedstawiona w: M. Csíkszentmihályi, Przeptyw. Psychologia optymalnego doświadczenia, tłum. M. Wajda-Kacmajor, Taszów 2005.

17 Por. tamże, s. 370.

18 Por. I. Jazukiewicz, Pedeutologiczna teoria cnoty, Szczecin 2012, s. 202.

19 J. Walkiewicz, Petna moc możliwości, dz. cyt., s. 91.

20 Tamże, rozdz. 6. Publikacja J. Walkiewicza została nagrodzona przez miesięcznik „Charaktery” Nagrodą Teofrasta. 
lekką i przyjemną, lecz wartościową i radosną poprzez doświadczenie jej sensowności. Można też wnioskować o sprzężeniu zwrotnym zachodzącym między tymi dwiema rzeczywistościami, bowiem - jak zauważa J. Walkiewicz - „poczucie sensu pomaga w rozwijaniu pasji do tego, co robimy"21. Podobnie istnieje współzależność celów i wysiłków, jakich wymaga ich realizacja: „początkowo cele uzasadniają podejmowane wysiłki, jednak później to wysiłek staje się uzasadnieniem celu"22, zwiększając jego wartość i sensowność. Fenomen pasji wyraża się między innymi w tym specyficznym współwystępowaniu zamiłowania i entuzjazmu $\mathrm{z}$ wysiłkiem i trudem; radości z poczuciem celowości i sensowności. Jest to zgodne z wcześniej przywołaną etymologią pasji, która łączy dwa rozumienia: zamiłowanie i cierpienie.

Pasja wymaga aktywności i zaangażowania, nie rozwija się w stanie bierności człowieka. Praca jest więc doskonałą przestrzenią do rozwijania pasji, jeśli człowiek doświadcza pracy jako wartości, która angażuje i daje poczucie zadowolenia. Pasja więc nie jest czymś, co się w pracy „przydarza”, bowiem wymaga świadomego zaangażowania osoby: znajdowania celowości, pokonywania trudów, koncentracji i przeżywania wykonywanych czynności, umiejętności cieszenia się z bezpośrednich doświadczeń, a nawet wyjścia poza egoizm i egocentryzm. Psychologiczna prawidłowość jest bowiem następująca: „Łatwiej jest odnaleźć sens, jeśli mamy poczucie, że to, co robimy, służy innym, ponieważ tak naprawdę jesteśmy dla ludzi, a nie z ludźmi”23. Konsekwencją braku pasji jest przeciętność osiąganych rezultatów pracy.

Rozważając naturę pasji i jej związki z pracą, można dostrzec w pasji warstwę filozoficzną, która „Zawiera w sobie określoną ideę człowieka, koncepcję świata i hierarchię wartości, którymi inspirują się posiadający pasję"24. Zajmowanie się znaczeniem pasji służy pogłębieniu refleksji na temat pracy i jakości jej doświadczania poprzez rozpatrywanie pracy nie tylko w kategoriach p rodukcji, ale przede wszystkim w kategoriach dobra człowieka, a więc jej wartości

21 Tamże, s. 90.

22 M. Csíkszentmihályi, Przeptyw, dz. cyt., s. 380.

23 J. Walkiewicz, Petna moc możliwości, dz. cyt., s. 98.

24 M. Dudzikowa, M. Nowak, Wprowadzenie, w: O pasjach cudzych i wtasnychprofesorowie, dz. cyt., s. 11. 
wychowawczej. Można też założyć, że poprzez pracę z pasją możliwe jest inspirowanie innych do przekształcania swojego życia - w życie z pasją, a to dodaje pasji wartości samowychowawczej.

Nie brakuje postaci, których praca z pasją przerodziła się w podziwiane przez innych życie $\mathrm{z}$ pasją. Amerykański pisarz Irving Stone w książce z roku 1934 zatytułowanej Pasja życia podją się trudnej próby ukazania życia i twórczości jednego z największych malarzy w historii, Vincenta van Gogha, którego obrazy zdobią największe muzea świata i są nieustającą inspiracją dla sztuki współczesnej. Pragnieniem ojca Vincenta było, aby syn został pastorem. Podtrzymałby w ten sposób rodzinną tradycję, a jednocześnie cieszyłby się powszechnym szacunkiem i miałby zapewnioną stabilizację finansową. Vincent próbował spełnić wolę ojca studiując teologię. Przerwał jednak edukację. Nie wiedział, co tak naprawdę chce robić w życiu, ale czuł, że tylko sztuka może dać mu szczęście. Próbował wytłumaczyć to domownikom, ale nie spotkał się ze zrozumieniem, więc opuścił dom rodzinny. Żył w biedzie, wyśmiewany przez współczesnych mu malarzy, ale malował. Za pasję tworzenia zapłacił nieustanną walką z ubóstwem, niemocą, szaleństwem i rozpaczą. Wkrótce po śmierci został uznany za jednego z największych artystów w historii.

Dziennikarka Anna Kamińska w książce z roku 2015 zatytułowanej Simona opowiedziała o niezwykłym życiu Simony Kossak. Miała być czwartym Kossakiem i kontynuować rodzinną tradycję malarstwa po pradziadku Juliuszu, dziadku Wojciechu i ojcu Jerzym. Chciała działać artystycznie, jak wszyscy w jej rodzinie. Uwielbiała twórczość swojej ciotki, Marii Pawlikowskiej-Jasnorzewskiej; nieco mniej drugiej ciotki - Magdaleny Samozwaniec. Zdawała do szkoły teatralnej, na polonistykę, a nawet na historię sztuki, żeby być bliżej tego świata. To jednak nie był jej świat. Wybrała własną niezależną drogę. Nieakceptowana przez najbliższych, zamieniła krakowską Kossakówkę na leśniczówkę Dziedzinka bez prądu w środku Puszczy Białowieskiej. Rozmawiała ze zwierzętami, mieszkała z dzikiem, przyjaźniła się $\mathrm{z}$ sarnami. $Z$ wykształcenia była profesorem nauk leśnych i biologiem; w życiu - naukowcem i pasjonatem. Zapisała rewolucyjną kartę w rozwoju zoopsychologii, ale też swojej rodziny.

To tylko dwa wybrane $z$ historii i współczesności przykłady pasji pracy, rozwiniętej aż do pasji życia. One wciąż trwają, ponieważ 
są podziwiane przez tych, których zachwyca taki sposób bycia: połączenie pracy i życia, dające poczucie sensu, choć pełne trudów i cierpienia.

\section{Konsekwencje instrumentalizacji pasji}

W opinii humanistów i pisarzy pasja jest traktowana jako rodzaj szczęścia, które jest przecież celem życia człowieka. Wyjątkowe są określenia używane dla jej opisu, dla przykładu:

Pasja to jak wielka zniewalająca miłość, to źródło radości, poczucie spełnienia i samorealizacji, to zanik poczucia czasu, to także siła aktywności i tworzenia [...], szansa uzyskania kompetencji, to cierpliwość, odporność na zmęczenie i stres, to lekarstwo przeciw nudzie, beznadziejności i wypaleniu zawodowemu, to poczucie bezinteresowności w działaniu, to poświęcenie, determinacja w dążeniu do celu. [...] pasja to wielka tajemnica, wymykająca się racjonalnemu przewidywaniu, pasja to emocje i uczucia najwyższego stopnia, to mechanizm kierunkowy zachowania się człowieka (motywacja) [...] pasja to siła, to zaangażowanie, to aktywność wbrew przeciwnościom, hamulcom środowiskowym i materialnym ${ }^{25}$.

Człowiek z pasją jest więc osobowościowo znacznie bogatszy od tego, kto jej nie doświadcza, ponieważ możliwości wpisane w pasję sprzyjają realizowaniu potencji rozwojowej tego, kto ją posiada.

Człowiek potrafi w życiu docenić szczęście, ale niestety także je zniszczyć. Podobnie może uczynić z pasją: skorzystać z jej potencji albo przekształcić ją w zjawiska sprzeczne. Pasja ma konsekwencje afirmujące dla podmiotu, dopóki ma dla niego charakter autoteliczny, natomiast przybiera postacie destrukcyjne, gdy jest instrumentalizowana. Podejmując zagadnienie instrumentalizacji pasji, socjolog Marek Krajewski wskazał i interesująco na przykładach wyjaśnił następujące jej współczesne formy ${ }^{26}$ :

1. Komodyfikacja pasji, czyli jej utowarowienie. Polega na wykorzystywaniu jej jako środka umożliwiającego sprzedaż produktów lub narzędzia, które samą osobę czynią bardziej wartościowym dobrem na rynku. Formą utowarowienia pasji jest na przykład:

25 S.L. Popek, O istocie i mechanizmach pasji, w: O pasjach cudzych $i$ wtasnych profesorowie, dz. cyt., s. 15 i 31.

26 M. Krajewski, Pasja i formy jej degeneracji, w: O pasjach cudzych $i$ wtasnych profesorowie, dz. cyt., s. 42-50. 
a) Marketing pasyjny, w którym sugeruje się konsumentowi, że może kupić nie tylko towar czy usługę, ale przede wszystkim zaangażowanie i uczucia włożone w ich powstanie. Próbuje się go przekonać, że motyw ekonomiczny ustąpił miejsce wewnętrznej, nieprzymuszonej woli producenta, czyli nie kieruje się on zarobkiem, lecz potrzebą samorealizacji. Jest więc szkoła z pasją, chleb wypiekany z pasją i fryzjer strzygący z pasją. Konsekwencją tej formy degeneracji pasji może być zatracanie jakościowych różnic między poszczególnymi sferami życia, działaniami, zjawiskami, np. miłość można kupić, dzieło sztuki nabywa się tak, jak warzywa, a czyjeś zrozumienie rezerwuje się, wykupując sesje terapeutyczne.

b) Projektowość pasji, czyli potraktowanie pasji jako zasobu zwiększającego wartość osoby na rynku pracy. Projektowanie pasji jako elementu $\mathrm{CV}$ daje konkurencyjną przewagę nad osobami o podobnych kwalifikacjach oraz kreuje jej podmiot jako kogoś, kto jest zmotywowany do działania. Można też pasjonować się tym, co stwarza możliwość rozwijania zawodowych kontaktów, a nawet tworzenia profesjonalnych sieci, opartych nie tylko na kontrakcie, lecz na przykład na podobieństwo uprawiania sportu czy koneserskiego gotowania. Pasja zostaje wykorzystana do skutecznego konkurowania $\mathrm{z}$ innymi.

2. „Hobbyizacja” pasji, czyli utożsamienie, a raczej pomylenie hobby i pasji. Hobby jest substytutem pasji w tym sensie, że może stanowić formę samorealizacji. Jednak jest ograniczone do czasu wolnego; ma nie kolidować z obowiązkami osoby i raczej stanowić nagrodę za ich wykonanie. Jego praktykowanie ma stwarzać możliwość zrealizowania tych potrzeb, których osobie nie udaje się zaspokoić w pracy, chociaż samą pracę ma ono przypominać poprzez niemarnowanie czasu, tworzenie, produktywność. Istotną różnicą jest także silne zmaterializowanie hobby jako praktyki: jego podejmowanie na ogół wymaga odpowiednich materiałów, narzędzi, miejsc czy strojów, by je urzeczywistniać czy prezentować. Zmaterializowanie jest źródłem różnicowania hobbystów: niektórzy z nich są nimi „bardziej” od pozostałych, bo np. posługują się bardziej profesjonalnym sprzętem.

3. Kultura karaoke, czyli samorealizowanie się poprzez udawanie kogoś, kim się nie jest. W przypadku np. amatorsko uprawianego malowania, rysowania czy muzykowania chodzi o naśladowanie 
artystów, by poczuć się tak, jak oni; w przypadku celebrytów - by wcielić się w rolę gwiazdy i poczuć się przez chwilę, jak ktoś powszechnie znany. W konsekwencji pasja zwalnia osobę z poszukiwania własnej drogi samorealizacji; zostaje zastąpiona gotowym scenariuszem, w dodatku skutecznie potwierdzonym osiągnięciem przez kogoś uznania.

4. „Nadwidzialność” pasji, czyli potraktowanie jej jako środek, dzięki któremu można zostać zauważonym. Unikatowość pasji sprawia, że może ona przejawiać się w ekscentryczny sposób poprzez zachowanie, wygląd czy sposób bycia. W ten sposób pasja przyciąga uwagę, a to z kolei generuje kapitał, o którego zdobycie wspólcześnie niektórzy rywalizują, prezentując swoje pasje na portalach społecznościowych, blogach czy w licznych programach typu $t a-$ lent show. Można nabrać przekonania jak wielu jest ludzi z pasją, tymczasem ta forma jej destrukcji wyraźnie wskazuje na deficyt uznania, a nawet poczucia tożsamości.

5. Pasja zdegenerowana $w$ separator. Ta forma ma miejsce wówczas, gdy pasja nie służy samorealizacji, lecz "wyrwaniu się" z tego, co na co dzień nudzi lub męczy: $\mathrm{z}$ rodzinnej wspólnoty, jeśli trwa ona wyłącznie z przyzwyczajenia lub obowiązku; z monotonnej codzienności, która przypomina, że nie udało się zrealizować życiowych zamierzeń; z zawodowych trosk. W takiej sytuacji pasja uzasadnia absencję we wspólnocie i pozwala zataić prawdziwy powód czyjejś nieobecności; poprzez oszukiwanie siebie i innych zwalnia tymczasowo $\mathrm{z}$ trudu zajmowania się rozwiązaniem jakiegoś problemu, a nawet daje poczucie szczęścia, gdy się nią zajmujemy. Zamiast motywować do zmiany rzeczywistości, pasja stanowi mur, który od niej oddziela.

6. Eksploatowanie osób z pasją przez system. Ta forma opiera się na założeniu, że osoba z pasją będzie działała w każdych warunkach, sama stworzy narzędzia swojej pracy, a nawet bezinteresownie wykona to, za co powinna mieć zapłacone. Rzeczywistość potwierdza to założenie: pomimo niskiej pensji, braku podstawowych warunków do pracy, niskiego statusu, a nawet niepoważnego traktowania w pracy przez przełożonych, osoba z pasją będzie niezwykle zaangażowana w pracę, odda czas, siły i dołoży swoje fundusze, bo bezwarunkowo kocha to, co robi. Krytyce nie podlegają owi pasjonaci, lecz ci, którzy ich pozytywne nastawienie do pracy wykorzystują. 
Formy instrumentalizacji pasji koncentrują uwagę na negatywnych zjawiskach, ale paradoksalnie podkreślają także jak niezwykle wartościowa jest sama pasja, skoro stała się przedmiotem tylu prób jej zawłaszczania przez współczesnego człowieka. Tymczasem prawdziwa pasja trwa tak długo, jak długo pozostaje przestrzenią wolności osoby i nie wynika z żadnej konieczności. Pedagogiczna interpretacja powinna więc być skoncentrowana na tworzeniu warunków sprzyjających kształtowaniu i rozwijaniu pasji, a nie wskazywaniu do czego może się ona przydać.

\section{Zakończenie}

Pasja jest związana z wolnością człowieka, ale jej rozwój może go samego zniewolić. Psycholog Stanisław L. Popek zwrócił uwagę, że niekiedy

pasja zmienia się w obsesję, ciemne i pokrętne zakamarki wyobraźni tworzą wyimaginowany świat, który zatraca i na koniec niszczy człowie$\mathrm{ka}$, a niekiedy także jego najbliższych. Bo pasja to także mania, to chory (patologiczny) przymus, to także narcyzm, a zatem bezkrytyczna wiara we własną doskonałość, namaszczenie, powołanie i wreszcie miłość (bezkrytyczną) do własnych dokonań ${ }^{27}$.

Próbując zrozumieć pasję, można więc mieć poczucie przebywania w przepaści: z jednej strony pasja jest odmianą szczęścia, a z drugiej - może być „piekłem na ziemi” i to uczynionym nie tylko sobie. Istnieje warunek chroniący przed wpadnięciem w tę przepaść: należy bezwzględnie połączyć wymiar pasji z moralnym usprawnieniem człowieka, które obejmuje jego rozum, wolę i uczucia. Bo przecież pasja to sensowne połączenie myśli, uczuć i działań scalonych nadrzędną wartością.

Zostało także powiedziane, że pasja zawiera w sobie określoną idę̨ człowieka, koncepcję świata i hierarchię wartości i że jest przeżywana w relacji z innymi. Pasja powinna więc być postępowaniem mądrościowym. A mądrość uczy, że w życiu nie chodzi wyłącznie o to, aby być szczęśliwym. Chodzi jeszcze o to, by inni z nami też byli szczęśliwi.

27 S.L. Popek, O istocie i mechanizmach pasji, w: O pasjach cudzych $i$ wtasnych profesorowie, dz. cyt., s. 31. 


\section{Bibliografıa}

Brückner A., Stownik etymologiczny języka polskiego, Wiedza Powszechna, Warszawa 2000.

Csíkszentmihályi M., Przeptyw. Psychologia optymalnego doświadczenia, tłum. M. Wajda-Kacmajor, „Moderator”, Taszów 2005.

Del Mazza V., Bajki i mądrość życiowa, tłum. L.T. Karłowicz, Verbinum, Warszawa 1999.

Dudzikowa M., Nowak M., Wprowadzenie, w: O pasjach cudzych $i$ wtasnychprofesorowie, red. M. Dudzikowa, M. Nowak, Wydawnictwo KUL, Lublin 2015, s. 7-12.

Dziewiecki M., Przedmowa, w: A. Grün, Życie i praca - duchowe wyzwanie, tłum. B.M. Kamińska, Edycja Świętego Pawła, Częstochowa 2007, s. 5-9.

Furmanek W., Rozumienie wartości pracy a orientacje życiowe cztowieka, „Pedagogika Pracy" 2004, nr 45, s. 59-67.

Jazukiewicz I., Pedeutologiczna teoria cnoty, Wydawnictwo Naukowe US, Szczecin 2012.

Krajewski M., Pasja i formy jej degeneracji, w: O pasjach cudzych $i$ wtasnych profesorowie, red. M. Dudzikowa, M. Nowak, Wydawnictwo KUL, Lublin 2015, s. 37-51.

Krąpiec M., Ludzki wymiar pracy, „Człowiek w Kulturze” 2005, nr 17, s. 7-18.

Pieńkos J., Stownik tacińsko-polski. Eacina w nauce i kulturze, Kantor Wydawniczy Zakamycze, Kraków 2001.

Popek S.L., O istocie i mechanizmach pasji, w: O pasjach cudzych $i$ wtasnych profesorowie, red. M. Dudzikowa, M. Nowak, Wydawnictwo KUL, Lublin 2015, s. 15-35.

Stownik języka polskiego, t. 1, red. M. Szymczak, PWN, Warszawa 1979.

Walkiewicz J., Petna moc możliwości, Helion, Gliwice 2015.

\section{ADRES DO KORESPONDENCJI:}

Dr hab. Iwona Jazukiewicz, prof. US

Uniwersytet Szczeciński

Wydział Teologiczny

Katedra Pedagogiki i Katechetyki

iwona.jazukiewicz@usz.edu.pl 